\title{
ÜBER DAS WESEN
}

\section{DER \\ NA T UR GESETZE.}

VON

G. C. ZIMMER.

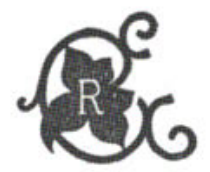

GIESSEN,

J. RICKER'SCHE BUCHHANDLUNG.

1893. 
Alle Rechte vorbehalten. 